\title{
Assessing the impact of globalization on human trafficking in Rwanda
}

\begin{abstract}
Ever since contemporary globalization came on the world scene around 1990s, free movement of goods, services and ideas grew as a result of reduced barriers to international movement trade and investment. The economic flow of goods and services has gone along with movement of people across the globe. The voluntary and involuntary movement of people occurs around world and is associated with opportunities that exist out there. Communication and flow of information is in real time in the current period from one corner of the globe to the other is occurring at high speed. Beliefs, ideas and culture have been relayed fast through the Internet, Smart Phones and other Communication devices. It is with this kind of awareness that Non- state actors such human traffickers operate and exploit people across the world. It is also easy to traffic people as national sovereignties for countries has been eroded by globalization, since national borders are permeable. Human trafficking has also been facilitated by spread of western culture and patriarchal approaches that go along with feminization of poverty and labor in the globalization era. Human security, particularly personal security has been greatly affected by globalization as victims of human trafficking suffer physical and psychological harm. The main objective of the present study was to understand the impact of globalization on human trafficking in Rwanda. Qualitative research design and documentary technique were adopted for the study. The findings of the study showed Rwanda is in the East African community which allows free movement of people and goods and so human trafficking has been facilitated in that sense. Further, there is foreign interference as Rwanda faces international threat of human trafficking. The present researcher recommends that Youth employment should be prioritized to enable young people fulfil their dreams. The public should be informed of the bad use of internet and law enforcement officials should be taught to track the internet and mobile phones users in order to arrest traffickers. More so, the youth should be provided with requisite knowledge and skills in order to realize their dreams. In addition, Human trafficking of persons cannot be combated in isolation. Regional and international cooperation is key.
\end{abstract}

Keywords: globalization, human, trafficking, security, state, sovereignty, actors, communication, technology, feminization, poverty
Volume 3 Issue I - 2019

\author{
Gacinya John \\ Department of Criminology \& Penology, Mount Kenya \\ University, Kenya
}

Correspondence: Gacinya John, Department of Criminology \& Penology, Mount Kenya University, Kenya, Tel + 250788309865, Email gacinyaj@yahoo.com

Received: December 24, 2018 | Published: February 14, 2019

\section{Introduction}

Globalization is the worldwide intensification of interconnectedness. Globalization involves widening, deepening, speeding up and growing of worldwide flows of capital and goods, information, ideas, people and forces that connect actors between countries.

There are four major types of global interaction and these include:

a) Communication, or the movement of information, including the transmission of beliefs, ideas, and doctrines

b) Transportation, the movement of physical objects, including war material and personal property as well as merchandise

c) Finance, the movement of money and instruments of credit

d) Travel and movement of persons. This includes voluntary movement which is travel and migration as well as involuntary movement which is human trafficking and forced migration

Globalization is a process of global integration and stretching of social, economic, cultural and political activities beyond political frontiers so that events and activities in one region come so significant to individuals and communities in distant regions of the globe. ${ }^{1}$ At its best, the process of globalization could lead to an inclusive worldwide culture, a global economy and above all, a shared awareness of the world as a single place. Globalization is liberalization, universalization and Westernization and supra-territorialization. ${ }^{2}$ Basing on the above global interactions, state security has been greatly affected as state sovereignty has been eroded with the emergence of non-state actors. In a globalized world, states no longer have full control over all the aspects of the life of their citizens and as a result large numbers of people have been trafficked. ${ }^{3}$ One aspect which indicates that states no longer have full control of their territory is given by United Nations Office on Drugs and Crime (2006) that defines human trafficking in persons as "the recruitment, transportation, harboring or receipt of persons, by means of the threat or use of force or other forms of coercion, of abduction, of fraud, of deception, of the abuse of power, or of a position of vulnerability or of the giving or receiving of payments or benefits to achieve the consent of a person having control over another person, for the purpose of exploitation". ${ }^{4}$

The link between globalization and human trafficking is that globalization encompasses involuntary movement of people across the world and in this case people who face exploitation mainly in terms of labor and sex. Globalization is also identified as a push 
factor like lack employment opportunities, lack of education, conflict, traditional and cultural practices. ${ }^{5}$

There are divergent views about the origins of globalization, but most researchers contend that globalization dates far deep in history. Some researchers indicate that globalization has been going on since the first movement of people out of Africa into other parts of the world about 3rd millennium BC, Others state globalization started when World System emerged or since the so-called axial age in the 1st millennium BC. Some argued that globalization started when great geographical discoveries arose in the 19th century, while others state well after the year 1945 and late 1980s. ${ }^{6}$

Sheffield ${ }^{6}$ also, finds that three periods have been identified to label the history of globalization and these are; archaic globalization, early modern globalization and modern globalization. Other than that globalization is thought to have started with the period of the Great Geographic Discoveries. Thus, there is Globalization 1, which is thought to have been there between 1492 and 1800. Globalization 2 to have been there between 1800-2000 and Globalization 3 between 2000 to the present. He states that Globalization 1 involves the globalization of countries, Globalization 2 involves the globalization of companies and Globalization 3 involves the globalization of individuals. Summing it up, globalization is of the past, present and the future. What is important to note that globalization has brought so many changes all around the world. People are aware of opportunities pertaining in other parts of the world and therefore the world is fed by opportunities offered by globalization. During globalization information flow is not limited to one place. Today people are able to know of the opportunities in their country and even abroad in a short time, quite different from what is was in the past decades where they only got information by way of mouth. Majority of people have access to internet, phones and television. as modern way of communication. Human trafficking is being continually fed by the opportunities being offered by globalization as well Human trafficking has increased remarkably since people have started showing interest in moving to other countries in search of opportunities of work. This happens when opportunities of globalization lead some uneducated or less aware people in the wrong hands. It is with this that human traffickers target women, young girls and children and promise them to send them to a foreign country and provide them jobs. They take a small amount of money and give girls fake passports and send them to another country. When they reach another country, they are told that they owe the agents who sent them a large amount of money and there is no other way to repay other than indulging themselves in sex work. ${ }^{7}$ In another development, wealthy, powerful and prestigious nations have taken advantage of globalization to exploit poor nations. Free movement of people and goods has contributed to the growing disparity between advanced and underdeveloped nations. In a similar fashion groups living in marginalized nations are driven to engage in illegitimate and exploitative activities such as human trafficking.

Thus, political changes in the Soviet Union and Balkan states in 1980s and 1990s led to the globalized sex trafficking in Western Europe Romania, Bulgaria, Ukraine, the Russian Federation and the Republic of Moldova are those states that were affected by human trafficking in the period. The end of the Cold War saw large numbers of laborers from Eastern to Western Europe some of who were sex workers. In 2005/2006, 51\% of the victims of human trafficking detected in Europe were from the Balkans and the former Soviet Union. This occurred because of globalization within the region. ${ }^{9}$
It is said that one-third of the population of Moldova has migrated out of the country. ${ }^{10}$ Other victims of human trafficking currently cross from Latin America to North America, but some Latin Americans are also found in destinations countries of Spain, Italy, Portugal, France, the Netherlands, Germany, Austria and Switzerland. Most of these are trafficked to Europe for sex trafficking. ${ }^{9}$

On the African continent, human trafficking became a criminal enterprise after 1980's due to globalization. It occurred more especially after great strides were made in in science and technology. Communication and transportation became easy and cheaper than before. Local and regional criminal networks are able to obtain victims of human trafficking who are shipped across the world for exploitation. ${ }^{11}$ Most of the victims come from West Africa, central Africa and horn of Africa. A good number of the victims migrate through Mediterranean Sea to Southern Europe. War torn countries such as Syria and Afghanistan also contribute greatly to the existence of migrants. The collapse of Soviet Union and the opening up of China as contributed to the greatest migration in history. Today there are as many migrants in China as there are in the United States. These movements inside and outside countries have been facilitated by the growth of cheap and easy transportation and communications. ${ }^{12}$

In addition, African countries have embraced equality between men and women in the current period. But this has not fully transformed the lives of women. With the spread of poverty in the Sub- Saharan Africa where Rwanda is situated women have moved to opportunity endowed North to change their status. ${ }^{13}$ Evidently, Human traffickers have embraced the advantages that accrue from the globalized economy and the technology that goes with it to take away migrants from original countries. Human traffickers have been mobile and acting in different multi criminal sectors and have been supported by use of the Internet, Smart Phones and other Communication devices have been used to recruit and market victims of trafficking human trafficking. ${ }^{14}$

\section{Problem statement}

Due to globalization about 199 million immigrants are thought to be living as foreigners in host countries. These migrants are not in most cases protected by the laws in the countries they live. They are therefore subject to exploitation in terms of labor and sex. Globalization has increased structural disparities between North and South and this has led to endless flow of people migrating from south to North in search for better life or even to escape discrimination and oppression. Undocumented or un documented migrant workers or mail order brides are such kind of women exposed to various forms of exploitation. ${ }^{15}$

The global North has been better than the global South in terms of economic advancement. Developing states produce raw materials which are sold at low prices to the developed world. The developed states process the raw materials and sell them at higher prices to the developing states and so the developed world have better terms of trade and therefore better balance of payments. The developed countries have therefore continued to become rich while the developing countries have grown poorer. This tendency has led to the development of migrants who always wish to migrate to the developed world and are in the end exploited in terms of labor and sex. Today one can find many migrants in China as there are in United states. 
In addition, the political developments in the Balkan states and former Soviet Union in 1980s and 1990s resulted into movements of women from the former Soviet Union and Balkan to Western Europe for sex work. Political instability in the region led to high unemployed among women and this subsequently led to high rate of organized crime that included human trafficking. Countries in the region remained with little accountability to their population and women had to go outside to take on foreign jobs as maids, nannies, dancers, and waitresses, only to find themselves in the hands of a pimp or brothel owner. ${ }^{16}$ Countries that were affected by the political instability were; Romania, Bulgaria, Ukraine, the Russian Federation and the Republic of Moldova. As a result, a third of Moldova's population moved out of the country to seek for employment. In a similar fashion, migrants from Latin America suffered hard labor and sexual exploitation as they escape poverty to North America and Western Europe over the years. During globalization era, tourism industry has developed because of easy transport and communication. There has been a growing number of international guests in hotels and guest houses in countries such as India and Thailand. There has also been need for the sexual services of call girls and as a result many school going girls have been lured into sexual exploitation. There is spread of poverty across many African countries including Rwanda. The development of information communication technology and easy with transport has opened Rwanda borders to the outside world. Rwandan people like other nationalities move outside to seek for economic opportunities that exist out there and are trafficked in the end. There is therefore need to think globally about human trafficking, but act locally in order detect and defeat human trafficking.

\section{Research objective}

To investigate the impact of globalization on human trafficking in Rwanda

\section{Literature review}

Shelley ${ }^{17}$ states that globalization has led to the decline of border control. The North American free trade agreement and the Schengen in Europe are the typical examples of free trade countries that have allowed free movement of people, goods and services and this kind of loose border control has resulted into human trafficking. She adds that globalization has led to the development of low cost, speedy communication by which traffickers have taken advantage of. Websites advertising sex tourism, child pornography and brides for marriage all are done through internet. Suzan ${ }^{18}$ hints that globalization involves travel, trade, and the displacement of families, all of which affect people, especially children. Children are mostly affected by human trafficking because of vulnerabilities faced as they depend on their parents for survival. Children who are excluded from the protection of their family for various reasons constitute an available pool of cheap labor and sex. Zeng ${ }^{19}$ argues that Globalization contributes to human trafficking, because globalization acts as an intermediary between peoples of the world. In the era of globalization victims know global opportunities and will migrate to tap the opportunities absent in their original countries. Likewise, traffickers will get information where vulnerable victims live and in such a situation trafficker will get chance to lure them into human trafficking. On the other hand, increased information flow will allow victims understand the risks of human trafficking lying ahead in the global world. He also finds that globalization will increase cooperation for both local governments and the international community in the fight against human trafficking. He adds that economic integration is likely to improve the standards of the citizens of source countries because of benefits of globalization.
Gilbertson, ${ }^{16}$ also asserts that globalization has created a universal culture where governments have created free-market economic systems to ease international trade. In this respect they have reduced barriers to international movement of goods, services and investments. He further mentions that globalization has had its negative side as the mainstream of the flow of goods, services and investments transnational crime of human trafficking has occurred. Others international crimes like drug trafficking, money laundering, arms trafficking and money counterfeit have also occurred with it.

Peerapeng ${ }^{20}$ mentions that economic globalization opens borders, transfers people for those willing and those who are forced. Due to the fact that human trafficking has become such a profitable and fastgrowing criminal activity, it is not only an outcome of globalization, but rather part of the globalization process with many isolated economic activities that may be good and bad. The good thing is that globalization brings greater advantages to individuals and countries already holding physical and human capital. The bad side is that Globalization has brought strained disparities within and between countries and this brings about cross-border migration. Global competing markets are inclined to result into inequality in incomes and wealth. It is inequality and disparity, coupled with the rise of consumerism that forces poor people into migration and in this way human trafficking is facilitated.

Angelina $^{21}$ argues that people in the deprived world change their mind in the way they look upon the world. They obtain information of the life opportunities that exist in different parts of the world through media. The life styles and living standards of people elsewhere prompt them when they consider their relative poverty and this has motivated them to migrate and realize their dreams. She adds that this happens because of globalization as closer integration of the countries and people of the world brings about by great reduction costs of transportation and communication, and the breaking down of artificial barriers to the flows of goods, services, capital, knowledge. She likens this trend to the opening of borders in Eastern Europe that led European Union to close borders for legal migration leaving the illegal migration to occur as poor people found it necessary to seek for better life using criminal networks.

Pawana $^{22}$ indicates that due to globalization the world has become so close. In India, tourism industry has developed because of easy communication and transport. Globalization has triggered a boom in the tourism industry. The growth of tourism has increased the number of hotels and guest houses for international guests who require the services of call girls. Poor school going girls are lured to be call girls to be sexually exploited by the international visitors. Media plays a key role in disseminating information about sex exploitation among the youth. Also, traffickers lure young girls to get married to rich men in the gulf countries. This is where you can find a minor married to a rich man who is three times older than her. Other girls are exported to work as shops, restaurants, gambling houses attendants where they are mentally and physically exploited. Marshall ${ }^{23}$ indicates that the impact of globalization is diverse. Economic integration has generated growth worldwide, thus more jobs have been obtained and standards of people have improved on a wide scale and as such poverty has been reduced in many countries. But economic integration takes place under considerable competition such that disparities in income and wealth occur across countries. The existence of inequality, poverty, and the rise in consumerism drives people to migrate with expectations of better standards of life elsewhere. In this respect when migration is orderly economic, social and cultural bonds between peoples and countries brings benefits while irregular migration 
results in vulnerabilities and human rights abuses that include human trafficking.

Aeillo ${ }^{24}$ supports the view that Globalization has done its best to improve trade, goods and people can move all over the world. But globalization has its ugly side, the world does not know what it transports. Globalization along with it embodies human trafficking. One area in which globalization has facilitated human trafficking is South Eastern Europe. This occurred after the fall of the Iron Curtain, the collapse of the Soviet Union and conclusion of the civil wars that plagued the Balkans in the 1990s. One typical area that demonstrated human trafficking on a large scale as a result of globalization in South Eastern Europe was the "Arizona Market". The market began after the 1990's instability in the Former Yugoslavia. It was a political intention behind the establishment of "Arizona Market" to bring people of Bosnia and Herzegovina, Croatia and Serbia together. Arizona market began as a meeting place for people who had ethnic tensions that would be ironed out through trade and other relations. Arizona market worked for a while to reduce ethnic tensions and later turned out to be a meeting point for organized criminals who were selling and purchasing of persons for sexual exploitation. Girls were purchased as slaves to go to United states, Western Europe and Israel. Many girls were lured into prostitution by International peace keepers.

Jones et al., ${ }^{25}$ argues that, although there are capital flows and emerging markets brought about by globalization, less attention has been given to a large number of people leaving the country looking for work outside their countries. There are over 199 million immigrants taken as foreigners in the host countries. These immigrants are not protected under the law by host countries as they protect their own citizens. They are therefore subject to exploitation as the ugly side of globalization.

$\mathrm{O}^{\prime} \mathrm{Brien}^{26}$ analyzes the dangers of globalization it has brought to the female sex. Globalization has harmed female sex because it goes beyond countries' borders and creates conditions conducive to human trafficking. The western culture and the and patriarchal approach have acted as 'pull' and 'push' factors for women leaving their countries of origin. Feminization of poverty has been entrenched in developing nations to the extent that women migrate to escape such a kind of deprivation. The growing economic disparity between the global North and the South has serious aggravated feminization of poverty and greatly facilitates sex trafficking. More so, The United nations and NATO forces are to blame for historical initiatives of providing the military to fulfil their sexual desires during military campaigns in Former Yugoslavia. The Balkan conflict serves as a good example that gave rise to human trafficking. The presence of the military in the Balkans created the demand for sex trafficking in the region as the United nations forces went in the region. This is the abuse of human rights in the globalization process. Further, O'Brien ${ }^{26}$ recognizes that women are the most disadvantaged social group in which globalization has left millions of women impoverished, laid off, paid the lowest salaries, and overworked. Women comprise nearly half of the world's migrants and are most vulnerable to exploitation as they face discrimination in hiring and employment and are often forced to work in industries with widespread labor abuses such as the sex tourist industry where they suffer exploitation and abuse. A vivid example of sex tourism is that prostitution through sex tourism has become one of Thailand's major financial resources as it helps the government pay off debts, which form a part of the cycle of economic abuse in globalization.

Katarina $^{27}$ states that world globalization is often characterized as a two-edged sword. Dominant policies linked to globalization have been fairly successful in facilitating economic growth and combating inflation in many rich countries. However, simultaneously this has caused increasing income polarization, persistently high levels of unemployment, and widespread social exclusion. The downsizing of the welfare system has in many instances led to the displacement of public welfare functions to the market or the home, and thereby increased the burden on women who in any way tend to do the major bulk of the labor in the invisible economy. The impact of globalization on women has been linked to an increase in sexual exploitation of women in the form of trafficking for prostitution particularly in countries undergoing rapid economic transformation. Onuoha ${ }^{28}$ argues that there is a relationship between globalization and human trafficking. He states that globalization has been associated with the current global capitalist production system and subsequent population movements in search for better opportunities. Capitalist production system has attracted cheap labor offered by migrants who include victims of human trafficking. The structural adjustment programs of 1980s are a product of globalization and are responsible for the creation of push factors such as poverty and unemployment in the developing countries that subsequently drove people to move to developed countries for better life.

Ahmed $^{29}$ indicates that human trafficking is part of global processes. He alludes to the fact that globalization has affected human security with all its seven facets- Economic security, food security, health security, environmental security and personal security that is freedom from threats by the state, groups, or individuals, Community security and political security. He again points out that human security is centered more directly around the protection of people, it means protection from sudden and hurtful disruptions in the patterns of daily life, whether at homes, at the job or in communities. He states that human security, particularly personal security has been greatly affected by globalization as victims of human trafficking suffer physical and psychological harm. Nazemi ${ }^{30}$ contributed to the understanding of the concept of globalization and how it facilitates human trafficking. He states that globalization has supplied people for forced labor, sex, construction work, agricultural work, marriage, adoption and child soldiers. Those who fall prey to the negative side of globalization become vulnerable outside their own countries and are trafficked in the end. Weather burn ${ }^{31}$ argues that globalization has not yielded prosperity, security and parity among countries that have embraced trade liberalization, in any case, globalization, has also led to increased economic inequality and a fall in the standard of living of those in under developed regions. Globalization has mainly benefited multinational corporations who get cheap labor at the expense of those who supply the labor. Globalization has dismantled borders and exposed nationals to external forces like human trafficking. Globalizations is merely obsessed with profit motive other than social goals.

Williamson $^{32}$ highlights that recent research indicates human trafficking has racial roots. The issue of 'Othering' or viewing and treating others as different because of class, gender, race and age leaves people at risk of human trafficking. People of color have been left vulnerable in United states and in some cases left people of color vulnerable to commercial exploitation. Othering, can create defenseless populations for human trafficking because they are prevented from gaining access to jobs and education. Viewing other people different has been noted in racialized sexual stereotypes and this has led to the trafficking of Asian women. There are constructs that have led to human trafficking; that women of certain races are exotic and desirable, that the poor women of certain races are cheap and the continued patriarchal domination against women of particular 
races. These constructs leave people with dire need of sexual services from vulnerable people.

Nagle $^{33}$ alludes to the fact that policy makers are more obsessed with economic integration, expansion of markets and profit during the period of globalization and less attention has been given to social integration and benefits of the community. There has been a drive to encourage profit maximization at the expense of community and individual rights, peoples' safety and security, autonomy and people's cultural identity. Countries have been at most pre-occupied with positioning themselves in international and regional markets and businesses, but failing to prosecute 'connect men' and human traffickers in the same region benefitting from the integration so created. Indeed, globalization has undermined solidification of democracy as income inequality resulting from globalization breeds social inequality, poverty as well as human trafficking. It seems there are many people who benefit from human trafficking to the extent that it will be difficult to eradicate. Those involved in human trafficking think they are justified to do so. There are many traffickers who recruit and transport victims of human trafficking and pocket billions of dollars. There are also multi-national companies who benefit from cheap labor by exploiting laborers from developing countries. There also weak and failing states that benefit from remittances of money from victims of human trafficking living in developed states. ${ }^{33}$

However, it must be acknowledged that globalization is not the inherent cause of human trafficking but an intermediary that helps to make it possible. Rapid advance in information, communication, and transportation technologies also drive economic growth, which is a factor in preventing human trafficking. At the same time information and communication technology is convenient to traffickers as it facilitated speedy, low-cost and anonymous communications that are beneficial to the activities of Human trafficking. ${ }^{19}$

Globalization impacts human trafficking with both 'push' and 'pull factors. Poverty is a 'push' factor in the developing countries that forces people to seek for ways in which they raise their standards of life while global culture is a 'pull' that attracts people to move to areas where they can acquire better life. ${ }^{34}$

Finally, Kingshott ${ }^{35}$ explains globalization as the world that is in motion. He states that globalization involves structures that facilitate the flow of capital, goods, information and the exchange of technology. But the structures also encompass global movements criminals and illegal goods that cross-national international borders resulting into organized crime which include human trafficking and human rights abuses.

\section{Research methodology}

In this study documentary research was applied. Documentary research method refers to the analysis of documents that contain data about the phenomenon under study. Previous studies were used to collect data and there was much reliance on description and interpretation of data rather than collecting raw data in accordance with Glenn. ${ }^{36}$ The documentary research method was used in investigating and categorizing physical sources, most commonly written and nonwritten documents, whether in the private or public domain as stated by Harelimana ${ }^{37}$ The data inclusion criteria depended on; authenticity, credibility, representativeness and meaning attached to evidence. ${ }^{38}$ Most of the obtained data was from; books, brochures and minutes of meetings, electronic journals, press releases, diaries, background papers, event programs, letters and memoranda, newspaper articles, press release, program proposals, radio and television program, institutional reports and public records.

\section{Results and discussion}

Browne points out that there are 159 million international migrants, about 90 million (49\%) are women and girls. The proportion of female international migrants is $51 \%$ in more developed regions and $54 \%$ in the United States. Historically, women migrated as dependent family members but today are increasingly part of transnational labor force moving to earn more money. Existing data tell us that most women migrants are employed in traditional female occupations of domestic work, health care, and teaching. Health care is prevalent as an employment in the United States, Asian immigrants represented nearly a quarter of the health care providers in public hospitals in major United states. The cause of migration of women has been feminization of poverty in developing states of which Rwanda is part. Browne continues to indicate that if the status of women can be improved in developing states then migration of women and human trafficking can reduce. Rwanda and Nigeria have done their best to have enacted laws that permit women to inherit land and this can probably reduce the number of women migrating to developed countries.

In addition, Rwanda National Police and National Public Prosecution $^{39}$ accepts that globalization which has been interpreted as free communication, free financial transfer, transportation of merchandise as well as free movement of people either voluntary or involuntary in this case human trafficking is an emerging crime and is prevalent in Rwanda. There has been economic globalization as Rwanda opened borders to the outside world. In other words, globalization has been a means with which human trafficking operates. With the corresponding increase in technology and communication human trafficking has flourished. More so, Isaboke \& Gacinya ${ }^{40}$ assert that human trafficking in Rwanda is difficult to combat since the establishment of the East African common market. Globalization was strengthened when the East African community allowed Free movement of people and goods. Rwandans like others are trafficked when they cross borders seeking for education and employment. Also, Rwanda human development report ${ }^{41}$ opines that, Rwanda is currently facing difficulties in eradicating human trafficking. Human traffickers have taken advantage of regional integration; there is no need for an individual to have sophiscated documents to go around the East African community countries. One needs only to have a national identity card to travel between Kigali and Mombasa. There are therefore human traffickers' networks in the region that deceive that engage young women and men of opportunities that exist for jobs and education elsewhere in the region. There is also rural-urban migration among the youth who aspire to get jobs in the urban and thereafter trafficked.

Rwanda immigration and emigration service ${ }^{42}$ observes that there is an issue of economic migrants as well as children trafficking to the outside world. The government of Rwanda has enacted laws to deal with the vice of child trafficking. The author underscores the importance of the law as Child trafficking is a global danger and a potential threat to Rwanda nationals as well. Further, Rwanda National Police $^{43}$ finds there are international threats to national security such as human trafficking that have come about because of globalization. There is foreign interference in national security and this has happened because of globalization and this is why African countries have remained in an exploitative situation. Human trafficking is an international and requires a unified international approach such as 
the regional cooperation of which Rwanda is part and parcel. In a similar way, women migration to the diaspora has been as a result of economic disparities between developing and developed countries continue to be key suppliers of work force to developed nations. Due to demographic changes developed countries have been dependent on women obtainable from poor countries even though they are paid less in terms of remuneration. ${ }^{44}$ The author indicates that migrant women in the diaspora and those of Rwandan origin have been very beneficial to their countries when they start micro enterprise as they return home from abroad. Due to globalization they acquire different gender roles beneficial to themselves and are able to raise their standards of living.

In the same vein, globalization and increasing structural disparity between North and South have led to an endless flow of people wanting better life and, in this case, Rwanda has been no exception. ${ }^{45}$ Migration to the North from the South has been endless especially among the African countries that face poverty and oppression. Conflicts in the great lakes have also contribute to migration and vulnerabilities with it and this has culminated into human trafficking. Internally, effects of Globalization can easily be identified among sex workers in Rwanda who move from the rural and settle Kigali city because of economic opportunities that exist there. In line with the fore mentioned assertion, Mutagoma ${ }^{46}$ estimates that there are about 3348 female sex workers in the city of Kigali prone to sex trafficking and related sexual transmitted diseases.

$\mathrm{Carol}^{47}$ highlights that the nexus between globalization and human trafficking can be found among those who migrate willingly and those are forced to move outside their countries reluctantly. Human trafficking is very much connected with rapidly globalizing world. Countries have open borders, easy communication, better transport have bolstered the forces of supply and demand for sex tourism in South Africa. There are under age young girls between 10 and 14 years estimated between 28000 and 30000 in the cities Cape Town, Johannesburg, Port Elizabeth and Durban in commercial sex exploitation because of the globalized world. These mainly come from East African countries, Rwanda inclusive. Misra ${ }^{48}$ finds that globalization has resulted in cross border movement of people in East Africa for both domestic labor and prostitution. Women and children are trafficked from Burundi and Rwanda to Kenya's coastal areas for sexual exploitation in the growing sex tourism industry. Some women and children work in massage parlors, where they are coerced into bonded labor in prostitution for provision of "escort services. Kahare ${ }^{49}$ also states that over 10,000 people are trafficked into Kenya's Coast Province each year. He indicates that trafficked children from Rwanda, Tanzania, Ethiopia, Somalia and Uganda work as domestic labourers, sex workers and cattle herders across Kenya. Runhovde ${ }^{50}$ states that, although human trafficking takes place between the borders of Uganda and Rwanda. Few victims of human trafficking are easily ferried across unnoticed. Without sufficient resources to counter and control peoples' movement, it is difficult to monitor who is trafficked and who is not since the nature of human trafficking has no complainant.

Nyerere center for peace and research ${ }^{51}$ has found out that youth have fallen victims of human trafficking as try to change their life for the better when they cross national borders of each partner state of East Africa. Traffickers have benefitted from weak systems and corruption in bid to control human trafficking. More appeal should be directed to the youth who have expectations of job opportunities and a better life outside their countries. Rwanda national youth council ${ }^{52}$ find that traces of internal as well as cross border trafficking occurs in Rwanda. Women and children are taken for commercial sex and hard labor. Poor women and children are attracted by job and education offers by traffickers but later on engage these in prostitution. According to Masanja ${ }^{53}$ there was a rise in gender-based violence from 4,614 reported cases in 2008 to 64,961 cases reported in 2013 in Rwanda which included human trafficking and domestic violence. Ngarambe $^{54}$ highlights that Rwandan girls easily fall victims of human trafficking because of unemployment. Once they have learned of opportunities in the diaspora, they are attracted to go there and later on trafficked. They are mostly trafficked to other East African countries, Asia, Europe. China and Malaysia and the countries that feature most as destination countries. The fact is that unemployment rate in Rwanda stands at 13 percent Kigali and over 120,000 job seekers flood the labor market each year from the emerging Universities and colleges. The girls are lured to believe there are jobs out there and are forced into commercial sex.

Finally, Musinguzi ${ }^{55}$ observed that Rwandan children who are in forced labor and sex trafficking inside and outside Rwanda. Rwandan girls are exploited in domestic labor with in the country, although few boys who are exploited in domestic work. Rwandan adults are exploited in agriculture work in Uganda and Kenya, some of them are found in prostitution in Burundi, Tanzania, Zambia, South Africa, UAE, Malaysia, China, United states and Europe. To a less extent Rwanda is destination country for human trafficking, although, women and girls in the neighboring countries can be found in Rwanda doing prostitution.

\section{Conclusion}

Globalization has not been the cause of human trafficking, but rather an intermediary that creates a situation for human trafficking to occur. Globalization ushered in information communication technology which facilitates human trafficking activities to happen. Globalization affects human trafficking with the help of 'push' and 'pull' factors. Poverty is a 'push' factor that drives people to seek alternative life opportunities as employment is a 'pull' factor that attracts people to countries that have better life standards.

Globalization has brought political, economic, social and environmental advantages into the world in which each country benefits, In the same vein globalization brought threats to national international security as well as violation of human rights in the name of human trafficking for which nations share. As nations share benefits as well as threats that accrue from globalization, they should also share the fight against threats such as human trafficking. Safe guarding national sovereignty would jeopardize national and international security. Globalization has resulted in socio-economic inequality between the North and the South and this has led to the feminization of poverty. Consideration for gender parity between men and women in the developing world has been an issue of globalization, but women status in terms of socio-economic development has remained low and this has prompted women to migrate affluent people in the North and are in the end trafficked. Globalization affects people when their human security is jeopardized resulting into human trafficking. This happens when there is failure to realize some income, food, good health and above all personal security and victims of human trafficking suffer physical and psychological harm.

It will be very difficult if not impossible to end human trafficking in environment where globalization operates. Profit motive drives human traffickers to recruit victims to distant destinations where billions of dollars are earned. Multi-national companies depend on cheap labor from developing countries while some countries obtain revenue from remittances of money from victims of human trafficking living in developed states. 


\section{Recommendation}

Local government should be in position to put in place protective measures for the youth. The most suitable approach would be to give young people the required knowledge, skills and values to make good choices, as well as scale up the opportunities for decent jobs. Youth employment should be prioritized to enable young people fulfil their dreams and protect them from being lured into human trafficking rackets. Human trafficking should be fought through effective border management so as to protect Rwandan nationals and other potential victims of these evils. The policy further recognizes that trafficking of persons cannot be combated in isolation but requires bilateral and multilateral collaborative efforts. Cooperation will continue to be strengthened to include all stakeholders such as international and regional organizations and the civil society in efforts to prevent and combat the trafficking of human beings. Concerned about the global threat child trafficking poses to the world, this policy encourages public awareness as a mechanism of fighting this threat. Immigration officers may question travelers about children accompanying them to or from Rwanda, or even question a child travelling alone. Individuals travelling with children are required to make sure that they possess all the necessary travel documents for the children. All travel agencies shall be notified of these regulations to inform the travelers in advance. Rwanda's migration policy is to raise awareness at various levels such as public information campaigns, publicizing the adverse effects of smuggling, trafficking and other related abuse, discouraging those who intend to undertake illegal movements, and warning those that are vulnerable to human trafficking, particularly women and children. Cooperation is key, both regional and international cooperation.

Reduction in exploitation, trafficking and smuggling of migrants can only be achieved through a transparent labor migration policy in East Africa. Collaboration is key between immigration and labor departments to assess labor market in consultation each partner state to identify and respond to current needs of workers.

\section{Acknowledgments}

None.

\section{Conflicts of interest}

The author declares that there are no conflicts of interest.

\section{References}

1. Oloo A. Globalization and International relations. Lecture notes, National Defense College, Nairobi; 2012. 7 p.

2. Hughes CW. Reflections on globalization, security and 9/11. UK: University of warwick; 2018. 18 p.

3. Dhidkova T. State's response to transnational human trafficking: the cases of Russia and Turkey. Thesis: İhsan Doğramac1 Bilkent University; 2011. $196 \mathrm{p}$

4. Rahman MA. Human trafficking in the era of globalization: The case of trafficking in the global market. Transience journal. 2011;3(1):1-18.

5. Melvin JL. Human trafficking: A theoretical application of Anomie on the tier placement system utilized by the U.S. State's department 'trafficking in persons' Report. Masters thesis, Grand Valley University; 2006. 150 p

6. Sheffield J. Globalization: Yesterday, Today and Tomorrow. Arizona: Emergent publications; 2013. 410 p.

7. Lopez JM. Joint task Force in Reducing Human trafficking. Thesis in management for public safety and homeland security professionals, Pace university; 2012. 36 p.
8. Tuttle OG. International response to human trafficking: A Comparative Secondary Data analysis of National characteristics. UNLV theses, dissertations, papers and capstones; 2017. 14 p.

9. UNODC. Trafficking in persons to Europe for sexual exploitation. Vienna: United Nations publication; 2013. 4 p.

10. Nafiu A. Effect of globalization: Terrorism and International crime. Journal of Business and Management. UK: Coventry university; 2016. $44 \mathrm{p}$.

11. Howard A. Organized crime. Boston: St. John's University; 2017.157 p.

12. Jordan A. Human trafficking and Globalization. USA: Center for American progress; 2004. 27 p.

13. Ligaya LM, Isidor. Globalization and third world women: Exploitation, Coping and Resistance. New York: Routledge; 2016. 167 p.

14. Gutauskas A. The globalization of organized crime and human beings. Lithunia: Supreme court; 2013. 4 p.

15. UNODC. The Globalization of Crime. A transnational organized crime assessment. Vienna: United Nations publication, 2010. 314 p.

16. Gilbertson MR. Globalization and sex trafficking industry: Examination of effects on regional value chain operations. Thesis: College of Saint Benedict/Saint John's University; 2015. 78 p.

17. Shelley L. Human trafficking: A global perspective. Cambridge: Cambridge University press; 2010. 357 p.

18. Susan T. Child soldiers, slavery and trafficking of children. Fordham international law Journal. 2007;31(2):428-498.

19. Zeng Y. Does globalization enhance countries'ability to combat human trafficking? Bard digital commons. Bard College; 2017. 282 p.

20. Peerapeng SR, et al. Impact of economic globalization on the human trafficking in the greater Mekong sub-region countries. Budapest: Agro inform publishing; 2017. pp. 124-125.

21. Angelina $\mathrm{S}$. Theory of push and pull factors: A new way of explaining the old. Conference Paper, Serbia: Belgrade, Kliment University; 2012. 2o p.

22. Pawana S. Effect of globalization on human trafficking and forced prostitution in India. 2002. $6 \mathrm{p}$

23. Marshall P. Globalization, Migration and Trafficking: Some Thoughts from the South-East Asian Region. Kuala Lumper: Paper for globalization workshop; 2001. 15 p.

24. Aiello A. Sex for Sale: Globalization and Human Trafficking. PRAGUE: Charles University; 2009. 93 p.

25. Jones L, et al. Globalization and Human Trafficking. Journal of sociology \& Social welfare. 2017;34(2):210-216.

26. O'brien C. An analysis of global sex trafficking. Indiana Journal of Political Science: Purdue University; 2008. pp. 4-10.

27. Katarina. Globalization and human rights of women. Abo Academic University of human Rights; 2012.90 p.

28. Onuoha B. Human trafficking in Africa: The role of universities in teaching and research. Journal of social science. 2013;34(1):61-72.

29. Ahmed NM. The globalization of insecurity: How the international economic order undermines human and national security on a world scale. United Kingdom: Institute for policy and development; 2004. 114

30. Nazemi N. How globalization facilitates human trafficking in persons ACTA Universitatis Danube 's. 2012;6(2):1-11.

31. Weatherburn A. The effects of political and socio-economic factors on human trafficking. Bulgaria (Sofia): Conference paper; 2015. 36 p. 
32. Williamson SH. Globalization as a racial project: Implications for human trafficking. Journal of international women studies. 2017;8(2):74-76.

33. Nagle L. Selling souls: The effect of globalization on human trafficking and forced servitude. Winsconsin international law journal 2008;26(1):153-156

34. Ondieki J. Human trafficking and its impact on National security in East Africa: A case study of the vice in Kenya. Master's thesis, Nairobi: Institute of diplomacy and international studies; 2017. 147 p.

35. Kingshott BF. Global society: Challenges of security and Policing Grand valley state university: Peer reviewed publication; 2016. 23 p.

36. Glenn B. Document analysis as a qualitative research method. Qualitative research journal. 2009;(9)2:27-40.

37. Harelimana JB. Research methodology for Economic Sciences and management. Musanze: INES-Ruhengeri; 2015. 429 p.

38. Ahmed JU. Documentary research Methods: New Dimensions. Indus Journal of Management \& Social Sciences.2010;4(1):1-14.

39. Rwanda National Police and National Public Prosecution. Analysis of causes of crimes, challenges and prevention strategies in Rwanda. Kigali; 2016. 148 p.

40. Isaboke PK, Gacinya J. Human trafficking incidence in Rwanda: Its Challenges, prevention and control. International Journal of Research in Sociology and Anthropology. 2017;3(1):19-29.

41. Rwanda Human Development. Decentralization and human development: Accelerating socio-economic transformation and sustaining accountable governance. Kigali. 2015. 197 p.

42. Rwanda immigration and emigration service. National migration policy and strategy. Kigali; 2012. 124 p.

43. Rwanda National Police. President Kagame: Let us not be easy targets for Fraudsters. The Police Magazine. Kigali: Rwanda National Police; 2016. $32 \mathrm{p}$.
44. Irena O. Gender, Poverty reduction and migration. UK: World Bank; 2010. $18 \mathrm{p}$.

45. Abdulraheem S, Oladipo AR. Trafficking in women and children: A hidden Health and Social problem in Nigeria. International Journal of Sociology and Anthropology. 2010; 2(3):35-39.

46. Mutagoma M. Estimation of Female Sex workers Population in Rwanda. International Journal of STDs \& AIDS. Kigali. 2015;26(11):810-814.

47. Carol A. An overview of human trafficking in Sub Sahara Africa. Conference on criminal trafficking and slavery. Pretoria: University of South Africa; 2006. 24 p.

48. Misra N. Trafficking of persons from a labor perspective: Kenyan Experience. Washington DC: Solidarity center; 2007. 9 p.

49. Kahare P. Horn of Africa: Human trafficking on the rise amid drought and famine. Kenya: Inter press service news agency; 2018.

50. Runhovde SR. Merely a transit country? Examining the role of Uganda in the transnational illegal ivory trade. Trends in Organized Crime. Oslo: Norwagian Police University; 2017. 4 p.

51. Nyerere Peace and Research. East African students' debate on East African Integration. Dar-Es-Salaam; 2018.

52. Rwanda National youth council. Towards a happy generation. Kigali: National Youth Council; 2015. 17 p.

53. Masanja G. Gender equality and Knowledge society. SIDA: Women in Global Science and Technology; 2016. 21 p.

54. Ngarambe A. Traffickers target young unemployed females. The East African. 2013. 2 p

55. Musinguzi B. Human trafficking: The modern form of slavery eating up East Africa. 2013. 